\title{
Çocuklarda Streptokoksik Tonsillofarenjit Tanısında Hızlı Antijen Testi ile McIsaac / Modifiye Centor Skorlamalarının Etkinliği
}

\section{Efficacy of Rapid Antigen Test and McIsaac / Modified Centor Scores for Diagnosis of Streptococcal Tonsillopharyngitis in Children}

\author{
${ }^{1}$ Mehtap BİNGÜL, ${ }^{2}$ Duygu SÖMEN BAYOĞLU, ${ }^{3}$ Tamay GÜRBÜZ, ${ }^{4}$ Pınar ALAGÖZ, \\ ${ }^{5}$ Sebahat AKSARAY, ${ }^{3}$ Çağatay NUHOĞLU
}

${ }^{1}$ Ömerli Devlet Hastanesi, Mardin, Türkiye

${ }^{2}$ Sağlık Bilimleri Üniversitesi Ümraniye Eğitim ve Araştırma Hastanesi Çocuk Gastroenteroloji Kliniği, İstanbul, Türkiye ${ }^{3}$ Sağlık Bilimleri Üniversitesi Haydarpaşa Eğitim ve Araştırma Hastanesi Çocuk Sağlığı ve Hastalıkları Kliniği, İstanbul, Türkiye ${ }^{4}$ Sinop Halk Sağlığı Laboratuarı, Sinop, Türkiye

${ }^{5}$ Sağlık Bilimleri Üniversitesi Haydarpaşa Eğitim ve Araştırma Hastanesi Tıbbi Mikrobiyoloji Kliniği, İstanbul, Türkiye

Mehtap Bingül: https://orcid.org/ 0000-0002-3425-5082

Duygu Sömen Bayoğlu: https://orcid.org/ 0000-0003-4049-0430

Tamay Gürbüz: https://orcid.org/ 0000-0003-1797-0364

P1nar Alagöz: https://orcid.org/ 0000-0002-2539-5091

Sebahat Aksaray: https://orcid.org/ 0000-0002-0552-1337

Çağatay Nuhoğlu: https://orcid.org/ 0000-0003-2187-4121

\section{ÖZ}

Amaç: Bu çalışmada çocuklarda grup A streptokok (GAS) infeksiyonlarını saptamada hızlı antijen testi, klinik bulgular ile McIsaac / modifiye Centor klinik skorlamalarının etkinliğinin saptanması amaçlandı.

Materyal ve Metot: Çalışmada akut tonsillofarenjitle başvuran 3-14 yaş arası olgular sosyodemografik ve semptomlar yönünden sorgulandı. Klinik bulguları ve McIsaac / modifiye Centor skorlamaları kaydedildi. Olguların tümüne hızlı streptokok antijen testi uygulandı ve boğaz kültürü çalışıldı.

Bulgular: Olguların \% 11 inde GAS kültürde üredi. Altı yaş ve üzeri çocuklarda kültür pozitifliği riski 4.8 kat daha fazla saptandı. Kas ağrısı ve tonsiller ödem ile kültür pozitifliği arasında istatiksel anlamlı ilişki mevcuttu Hızlı antijen testi streptokok tonsillofarenjiti tanısında \%75 duyarlılığa, \%100 özgüllüğe sahip olarak bulundu. McIsaac / modifiye Centor skoru 4-5 olan çocuklarda hızlı antijen testi streptokok tonsillofarenjiti tanısinda $\% 80$ duyarl1l1k, \%100 özgüllük gösterdi.

Sonuç: Akut tonsillofarenjitte gereksiz antibiyotik kullanımı önemli bir sorundur. Bu nedenle GAS infeksiyonunu düşündüren her olguda boğaz kültürünün istenmesi ve ona göre hareket edilmesi ideal olandır. Ancak kültürün yapılamadı $\breve{g}_{1}$ durumlarda tanı ve tedaviyi yönlendirmede hizlı strep testi ve McIsaac / modifiye Centor skorlamas1 etkilidir.

Anahtar Kelimeler: Bakteriyel antijenler, çocuk, streptokokal enfeksiyonlar

\section{ABSTRACT}

Objective: We aimed to determine the efficacy of rapid antigen tests, clinical signs, and McIsaac / modified Centor clinical scoring systems in the diagnosis of Group A streptococcus (GAS) at children.

Materials and Methods: Subjects aged 3-14 years who presented with acute tonsillopharyngitis were questioned about their sociodemographic properties and symptoms. Their clinical signs and McIsaac / modified Centor scores were recorded. They underwent a rapid streptococcal antigen test and throat culture sampling.

Results: GAS proliferated in culture $\% 11$ of cases. The risk of culture positivity was 4.8 times greater in children aged 6 years or older. There was a significant correlation between culture positivity and muscle pain, tonsillar edema. Rapid strep test had a sensitivity of $75 \%$ and a specifity of $100 \%$ for the diagnosis of streptococcal tonsillopharyngitis. Rapid strep test showed a sensitivity of $80 \%$ and a specifity of $100 \%$ in children with a McIsaac / modified Centor score of 4-5.

Conclusion: Unnecessary antibiotic use for tonsillopharyngitis is an important problem. Therefore, it is ideal to order throat culture and act accordingly in every case suggesting GAS infection. However, when culture is not possible, rapid strep testing and McIsaac / modified Centor scoring are effective in guiding diagnosis and treatment.

Keywords: Bacterial antigens, child, streptococcal infections

\section{Yayın Bilgisi / Article Info:}

Gönderi Tarihi/ Received: 13/07/2020

Kabul Tarihi/ Accepted: 20/10/2020

Online Yayın Tarihi/ Published: 31/12/2020

Elmalıkent Mah, Adem Yavuz Cd.,34764, Ümraniye/İstanbul

Turkey

Tel: +90 5053762416

E-mail: duygubayoglu@hotmail.com

Atıf / Cited: Bingül M, et al. Efficacy of Rapid Antigen Test and McIsaac / Modified Centor Scores for Diagnosis of Streptococcal Tonsillopharyngitis in Children. Online Türk Sağllk Bilimleri Dergisi 2020;5(4):553-562. doi: 10.26453/otjhs.764484 


\section{INTRODUCTION}

Acute tonsillopharyngitis is one of the most common causes of seeking medical attention in childhood. ${ }^{1,2}$ Most cases are caused by viruses including rhinovirus, coronavirus, adenovirus, influenza virus, and parainfluenza virus. ${ }^{2}$ Group A streptococcus (GAS) is the most commonly encountered bacterial agent of tonsillopharyngitis; it may give rise to suppurative complications such as otitis media, sinusitis, peritonsillar abscess, and cervical adenitis, and non-suppurative complications such as acute rheumatic fever and acute glomerulonephritis unless timely diagnosed and appropriately managed., Therefore, both diagnosing and treating GAS in a timely fashion and preventing its complications especially in countries like ours where the incidence of acute rheumatic fever is high is of paramount importance, as is avoiding unnecessary antibiotic use. $^{5,6}$

The distinction between viral-bacterial agents of acute tonsillopharyngitis solely based on clinical signs is most unlikely. Several clinical scoring systems have been devised to help distinguish efforts. Those scoring systems were named as McIsaac and modified Centor. ${ }^{7-9}$ Throat cultures are the gold standard test for the diagnosis of GAS. However, as it takes 24-48 hours to get results, rapid antigen tests are also utilized in diagnosis. A rapid strep test is on them. ${ }^{10}$

In the present study, it was aimed to determine the incidence of GAS infection in throat cultures, to study its correlation with clinical scores and clinical signs, and to establish the diagnostic efficacy of rapid strep test among children presenting with acute tonsillopharyngitis.

\section{MATERIALS AND METHODS}

A cross-sectional study was designed to determine the incidence of GAS in throat cultures, to study its correlation with clinical scores, and to establish the diagnostic efficacy of rapid strep test in children aged 3-14 years presenting to Haydarpasa Numune Training and Research Hospital with presumed acute tonsillopharyngitis. This study was conducted among 119 pediatric patients aged 3-14 years who presented to Haydarpasa Numune Training and Research Hospital with presumed acute tonsillopharyngitis between September and October 2012, and whose parents gave informed consent. Our study was approved by the Ethics Committee of Hay- darpasa Numune Training and Research Hospital (Date: 24.9.2012, decision no: 2012/68).

The patients were questioned about their sociodemographic properties and symptoms using a questionnaire form. A detailed physical examination was performed, and the findings were recorded in all patients. These findings were used to calculate and record McIsaac / modified Centor scores. McIsaac / modified Centor score was calculated as follows: fever $>38^{\circ} \mathrm{C} 1$ point; absence of cough 1 point; tender anterior cervical adenopathy 1 point; exudative or edematous tonsils 1 point; age 3-14 years 1 point. Throat swab samples were taken from the patients' posterior pharynx and tonsils and sent to the microbiology laboratory. The samples were first inoculated onto 5\% sheep blood agar. They were incubated at $37{ }^{\circ} \mathrm{C}$ for 48 hours. The culture plates were checked every 24 hours. Suspected beta-hemolytic streptococcal colonies were typed using routine microbiological methods (PYR positivity, bacitracin sensitivity). After inoculation onto sheep blood agar, a rapid streptococcal antigen screening test (ioline $\mathrm{SD}$, Korea) were studied from dry swabs in compliance with the manufacturer's instructions. The culture results were compared with sociodemographic and clinical features and scoring results. Additionally, the diagnostic efficacy of a rapid strep test was investigated.

Statistical Analysis: The study data were analyzed with SPSS (Statistical Package for Social Sciences) for Windows 15.0 software package. Descriptive statistics included mean, standard deviation. Qualitative variables were compared using the Chi-Square test and Fisher's Exact test. Diagnosis screening tests were used to calculate sensitivity and specifity values. Statistical significance was set at $\mathrm{p}<0.05$.

\section{RESULTS}

This study enrolled a total of 119 children. The age range of the study subjects was 3-14 years, and their mean age was 5.94 \pm 3.36years. Of 119 subjects, $37.8 \%$ were girls and $62.2 \%$ were boys.

There was a significant correlation between age and culture positivity $(\mathrm{p}<0.05)$. The rate of culture positivity among children aged six years or older $(18 \%)$ was significantly higher than that among children aged 3-5 years $(4.3 \%)$. The risk of culture positivity was 4.8 times greater in children aged six years or older (Odds Ratio: 4.829; 95\% CI:1.235-18.882) (Table 1). 
The rate of culture positivity in children with muscle pain $(17.5 \%)$ was significantly greater than that of children without muscle pain $(3.2 \%)$. The risk of culture positivity was 6.3 times greater in children with muscle pain than those without (Odds Ratio: 6.383; 95\% CI:1.334-30.541).

There was a significant correlation between tonsillar edema and culture positivity $(p<0.01)$. The rate of culture positivity in children with tonsillar edema $(40 \%)$ was significantly greater than that of children without $(5.8 \%)$. The risk of culture positivity was 10.8 times greater in children with tonsillar edema than those without (Odds Ratio: 10.889; 95\% CI:2.904-40.825) (Table 1).

Twelve (11\%) of 119 children had a positive throat culture. Nine $(75 \%)$ of twelve children with positive throat culture had a positive rapid strep test while three $(25 \%)$ of them had a negative rapid strep test (Figure 1). In the present study, the rapid strep test had a sensitivity of $75 \%$ and a specifity of $100 \%$ for the diagnosis of streptococcal tonsillopharyngitis. The positive predictive value of the test was $100 \%$ and the negative predictive value $97.27 \%$ (Table 2 ). There was a significant difference between culture positivity by McIsaac / modified Centor score $(\mathrm{p}<0.01)$. While $2.4 \%$ of children with a McIsaac / modified Centor score of 2-3 had a positive culture, $28.6 \%$ of those with a McIsaac / modified Centor score of 4-5 had a positive culture. There was a significant difference between rapid strep test positivity by McIsaac / modified Centor score $(\mathrm{p}<0.01)$. While $1.2 \%$ of children with a McIsaac / modified Centor score of 2-3 had a positive rapid strep test, $22.9 \%$ of those with a McIsaac / modified Centor score of 4-5 had a positive rapid strep test (Table 3).

The results of the present study showed that the rapid strep test had a sensitivity of $50 \%$ and a specifity of $100 \%$ for the diagnosis of streptococcal tonsillopharyngitis among children with a McIsaac / modified Centor score of 2-3. Among children with a McIsaac / modified Centor score of 4-5, the rapid strep test had a sensitivity of $80 \%$ and a specifity of $100 \%$ for the diagnosis of streptococcal tonsillopharyngitis (Table 4).

\section{DISCUSSION AND CONCLUSION}

GAS is the most common pathogen leading to bacterial tonsillopharyngitis. It is the sole clinical condition where antimicrobial therapy is indicated. The throat culture is the gold standard for its diagnosis. ${ }^{10}$ The incidence of GAS in acute tonsillopharyngitis ranges between $15 \%$ and $30 \% .{ }^{11-13}$ The incidence of
GAS reported by the present study is below the literature reports. However, given the higher incidence of streptococcal pharyngitis in winter and early spring, this finding may have resulted from the important fact that this study was conducted in fall. ${ }^{10}$ This represents a limitation of our study.

Our study detected a significant correlation between culture positivity and age $(p<0.05)$. The risk of culture positivity was 4.8 times greater in children aged six years or older than those aged 3-5 years. Several studies in the literature scrutinized the same topic. A meta-analysis of 29 studies showed that the incidence of streptococcal pharyngitis was lowest among children aged less than 5 years than the other age groups among children presenting with sore throat. $^{14}$

Our study also investigated the correlation between clinical signs and culture positivity. There was a significant correlation between muscle pain and culture positivity $(\mathrm{p}<0.05)$. The rate of culture positivity was 6.3 times greater in children with muscle pain. Little et al reported that muscle pain, sore throat, and inflamed tonsils were correlated with streptococcal culture positivity. ${ }^{15}$

Likewise, a study from India demonstrated a significant correlation between fever, painful swallowing, enlarged tonsils, and tender lymphadenopathy, and the rate of culture proliferation of Group A streptococci. ${ }^{16}$ In our study, $11 \%$ of children with a sore throat and difficulty swallowing had culture positivity whereas none of those without sore throat or difficulty swallowing had a positive culture. However, this difference was not statistically significant.

Our study found a significant correlation between tonsillar edema and culture positivity $(\mathrm{p}<0.01)$. The risk of culture positivity was 10.8 times greater in children with tonsillar edema. Similarly, Attia et al. found a significant correlation between tonsillar edema and culture positivity among children with acute tonsillopharyngitis. ${ }^{17}$ Others showed a correlation between tonsillar edema and streptococcal culture positivity. ${ }^{18,19}$ Among them, Barbosa et al reported that the absence of viral signs such as running nose and conjunctivitis were also significantly correlated to streptococcal culture positivity. Our study did not reveal such a correlation. ${ }^{19}$

Rapid strep tests that have recently been developed for laboratory diagnosis of streptococcal tonsillopharyngitis have offered several advantages, particularly in terms of rapidity of testing, thanks to their simple use and ability to give results in as short as 10 minutes. However, lacking sensitivity and 
specifity of $100 \%$ prevents them from being utilized in the diagnostic process. Studies performed so far have reported varying sensitivity and specifity values. In a Cochrane analysis of 98 studies performed in children, rapid strep test was found to have a sensitivity of $85.6 \%$ and a specifity of $95.4 \%$, with sensitivity levels being variable among studies whereas specifity levels being more stable. ${ }^{20}$ We detected that $9(75 \%)$ of our subjects with positive throat culture had a positive rapid strep test and $3(25 \%)$ had a negative rapid strep test. In other words, rapid strep test had a sensitivity of $75 \%$ a specifity of $100 \%$, a positive predictive value of $100 \%$, and a negative predictive value of $97.27 \%$. In general, our study results are in accordance with the literature reports.

The causative agents for acute tonsillopharyngitis are viruses in $70-80 \%$ of affected individuals; however, as the distinction between bacterial and viral etiologies is a difficult task, patients are mostly prescribed unnecessary antibiotic therapy. On the other hand, an untreated GAS infection may lead to suppurative and non-suppurative complications. Therefore, some clinical scoring systems have been developed to aid in recognizing GAS infection.

The most well-known among those scoring systems is McIsaac / modified Centor. ${ }^{8}$ Hence, we investigated the correlation of that scoring with throat culture positivity and rapid strep test positivity. Among subjects with a McIsaac / modified Centor score of 2-3, $2.4 \%$ had a positive culture while $28.6 \%$ of those with a McIsaac / modified Centor score of 4-5 had culture positivity. That is, there was a markedly significant correlation between McIsaac / modified Centor score and culture positivity $(p<0.01)$. Similarly, there was a markedly significant correlation between McIsaac / modified Centor score and rapid strep test positivity $(\mathrm{p}<0.01)$. While the strep test was positive among patients with a McIsaac / modified Centor score of $2-3$, it was positive of $22.9 \%$ of those with a McIsaac / modified Centor score of 4-5. Some studies have reported that culture positivity parallelly increased with increasing McIsaac / modified Centor score. ${ }^{21-23}$ Cohen et al detected a significant correlation between McIsaac / modified Centor score and culture positivity. ${ }^{23}$ They found that children with a McIsaac / modified Centor score of 1 and 2 had a throat culture positivity of $24 \%$ while those with a score of 4 or greater had a corresponding rate of $41.2 \%$. Those findings are in line with ours. Similarly, they reported a sensitivity of $75 \%$ for a McIsaac / modified Centor score of 1 and 2, which increased to $89 \%$ in the presence of a
McIsaac / modified Centor score of 4 and 5 although the specifity was reduced from $97 \%$ to $92 \%$. Our study established a sensitivity of $50 \%$ for a rapid strep test when the McIsaac / modified Centor score was 2-3 and $80 \%$ when the McIsaac / modified Centor score was $4-5$. Specifity remained constant at $100 \%$ for both conditions.

In conclusion, our study found a sensitivity of $75 \%$ and a specifity of $100 \%$ for the rapid strep test. It also showed that McIsaac / modified Centor scores were helpful for a distinction between viral and bacterial agents in the diagnosis of acute tonsillopharyngitis. It also showed that the sensitivity increased when the scores and rapid strep tests were used in combination.

Ethics Committee Approval: This study was performed after it was approved by the Haydarpasa Numune Training Research Ethics Committee (Date: 24.9.2012, decision no: 2012/68).

Conflict of Interest: No conflict of interest was declared by the authors.

Author Contributions: Concept - CN, DSB, TG; Supervision - CN, SA; Materials - MB, PA; Data Collection and/or Processing - MB, PA; Analysis and/ or Interpretation - MB, TG; Writing - MB, DSB, CN, SA.

Peer-review: Externally peer-reviewed.

\section{REFERENCES}

1. Bisno AL. Acute pharyngitis. N Engl J Med. 2001;344(3):205-211.

2. Regoli M, Chiappini E, Bonsignori F, Galli L, Martino de M. Update on the management of acute pharyngitis in children. Ital $\mathrm{J}$ Pediatr. 2011;37(1):10.

3. Weber R. Pharyngitis. Prim Care Clin Office Pract. 2014;41(1):91-98.

4. Ralph PA, Carapetis JR. Group A streptococcal diseases and their global burden. Curr Top Microbiol Immunol. 2013;368:1-27.

5. Güler M, Laloğlu F, Olgun H, Ceviz N. Clinical characteristics of pediatric patients with firstattack acute rheumatic fever following the updated guideline. Turk Pediatri Ars. 2019;54(4):220224.

6. Narin N, Mutlu F, Argun M ve ark. Incidence and clinical features of acute rheumatic fever in Kayseri, Central Anatolia, 1998-2011.Cardiol Young. 2015;(4):745-751.

7. Centor RM, Witherspoon JM, Dalton HP, Brody $\mathrm{CE}$, Link K. The diagnosis of strep throat in 
adults in the emergency room. Med Decis Making. 1981;1(3):239-246.

8. McIsaac WJ, White D, Tannenbaum D, Low DE. A clinical score to reduce unnecessary antibiotic use in patients with a sore throat. CMAJ. 1998;158(1):75-83.

9. Choby BA. Diagnosis and treatment of streptococcal pharyngitis. Am Fam Physician. 2009;79 (5):382-390.

10. Anjos LM, Marcondes MB, Lima MF, Mandelli AL, Okoshi MP. Streptococcal acute pharyngitis. Rev Soc Bras Med Trop. 2014;47(4):409-413.

11. Kalra MG, Higgins KE, Perez ED. Common questions about streptococcal pharyngitis. Am Fam Physician. 2016;94(1):24-31.

12. Smeesters PR, Campos DJR, Melderen LV, Aguiar E, Vanderpas J, Vergison A. Pharyngitis in low-resources settings: A pragmatic clinical approach to reduce unnecessary antibiotic use. Pediatrics. 2006;118(6):1607-1611.

13. Topyaka E, Yildırım T, Arsan S. Isolation ratio, and T-serotyping group A streptococci from pediatric upper respiratory tract infections in Turkey. Anatol J Cardiol. 2005;5(4):302-304.

14. Shaikh N, Leonard E, Martin JM. Prevalence of streptococcal pharyngitis and streptococcal carriage in children: a meta-analysis. Pediatrics. 2010;126(3):557-564.

15. Little P, Hobbs FD, Mant D, McNulty CA, Mullee M. Incidence, and clinical variables associated with streptococcal throat infections: a prospective diagnostic cohort study. $\mathrm{Br} \mathrm{J}$ Gen Pract. 2012;62(604):787-794.

16. Bhalla K, Bhardwaj P, Gupta A, Mehra S, Nehra D, Nanda S. Role of epidemiological risk factors in improving the clinical diagnosis of streptococcal sore throat in pediatric clinical practice. J Family Med Prim Care. 2019;8(10):3130-3135.

17. Attia M, Zaoutis T, Eppes S, Klein J, Meier F. Multivariate predictive models for group A betahemolytic streptococcal pharyngitis in children. Acad Emerg Med. 1999;6(1):8-13.

18. Tesfaw G, Kibru G, Mekonnen D, Abdissa A. Prevalence of group A $\beta$-hemolytic streptococcus among children with pharyngitis in Jimma town, Southwest Ethiopia. Egyptian Journal of Ear, Nose, Throat, and Allied Sciences. 2015;16(1):35 -40 .

19. Júnior ARB, Oliveira CDL, Fontes MJF, Lasmar LMLBF, Camargos PAM. Diagnosis of streptococcal pharyngotonsillitis in children and adoles- cents: clinical picture limitations. Rev Paul Pediatr. 2014;32(4):285-291.

20. Cohen JF, Bertille N, Cohen R, Chalumeau M. Rapid antigen detection test for group A streptococcus in children with pharyngitis. Cochrane Database of Systematic Reviews. 2016. doi: 10.1002/14651858.CD010502.pub2

21. Fine AM, Nizet V, Mandi KD. Large-scale validation of the Centor and McIsaac scores to predict group A streptococcal pharyngitis. Arch Intern Med. 2012;172(11):847-852.

22. Saddik, IAB, Munibari AA, Alhilali AM ve ark. Prevalence of group A beta-hemolytic streptococcus isolated from children with acute pharyngotonsillitis in Aden, Yemen. Trop Med Int Health. 2014;19(4):431-439.

23. Cohen JF, Chalumeau M, Levy C ve ark. Spectrum and inoculum size effect of a rapid antigen detection test for group A streptococcus in children with pharyngitis. PLoS One. 2012;7 (6):39085 
Table 1. The correlation between culture positivity and demographic data, clinical signs, and the appearance of the pharynx and the tonsils.

\begin{tabular}{|c|c|c|c|c|}
\hline Demographic Data & & $\begin{array}{c}\text { Culture Positive } \\
\text { n (\%) }\end{array}$ & $\begin{array}{c}\text { Culture Negative } \\
\text { n (\%) }\end{array}$ & $\mathbf{p}$ \\
\hline \multirow[t]{2}{*}{ Age } & 3-5 year & $3(4.3 \%)$ & $66(95.7 \%)$ & \multirow[t]{2}{*}{$0.015 *$} \\
\hline & 6 years or older & $9(18.0 \%)$ & $41(82.0 \%)$ & \\
\hline \multirow[t]{2}{*}{ Sex } & Girl & $6(13.3 \%)$ & $39(86.7 \%)$ & \multirow[t]{2}{*}{0.359} \\
\hline & Boy & $6(8.1 \%)$ & $68(91.9 \%)$ & \\
\hline \multicolumn{5}{|l|}{ Clinical signs } \\
\hline \multirow[t]{2}{*}{ Fever } & Yes & $12(10.7 \%)$ & $100(89.3 \%)$ & \multirow[t]{2}{*}{1.000} \\
\hline & No & $0(0.0 \%)$ & $7(100.0 \%)$ & \\
\hline \multirow[t]{2}{*}{ Halitosis } & Yes & $10(10.9 \%)$ & $82(89.1 \%)$ & \multirow[t]{2}{*}{0.732} \\
\hline & No & $2(7.4 \%)$ & $25(92.6 \%)$ & \\
\hline \multirow[t]{2}{*}{ Difficulty swallowing } & Yes & $12(11.8 \%)$ & $90(88.2 \%)$ & \multirow[t]{2}{*}{0.211} \\
\hline & No & $0(0 \%)$ & $17(100.0 \%)$ & \\
\hline \multirow[t]{2}{*}{ Muscle Pain } & Yes & $10(17.5 \%)$ & $47(82.5 \%)$ & \multirow[t]{2}{*}{ 0.011* } \\
\hline & No & $2(3.2 \%)$ & $60(96.8 \%)$ & \\
\hline \multirow[t]{2}{*}{ Cervical Lap } & Yes & $1(3.3 \%)$ & $29(96.7 \%)$ & \multirow[t]{2}{*}{0.878} \\
\hline & No & $11(12.4 \%)$ & $78(87.6 \%)$ & \\
\hline \multicolumn{5}{|c|}{ Appearance of the pharynx and the tonsils } \\
\hline \multirow[t]{2}{*}{ Tonsillar hyperemia } & Yes & $12(10.3 \%)$ & $105(89.7 \%)$ & \multirow[t]{2}{*}{1.000} \\
\hline & No & $0(0.0 \%)$ & $2(100.0 \%)$ & \\
\hline \multirow[t]{2}{*}{ Tonsillar edema } & Yes & $6(40.0 \%)$ & $9(60.0 \%)$ & \multirow[t]{2}{*}{$0.001 * *$} \\
\hline & No & $6(5.8 \%)$ & $98(94.2 \%)$ & \\
\hline \multirow[t]{2}{*}{ Tonsillar exudate } & Yes & $1(2.4 \%)$ & $40(97.6 \%)$ & \multirow[t]{2}{*}{0.056} \\
\hline & No & $11(14.1 \%)$ & $67(85.9 \%)$ & \\
\hline \multirow[t]{2}{*}{ Palatal petechiae } & Yes & $1(16.7 \%)$ & $5(83.3 \%)$ & \multirow[t]{2}{*}{0.479} \\
\hline & No & $11(9.7 \%)$ & $102(90.3 \%)$ & \\
\hline
\end{tabular}

Chi-square test and/or Fisher's Exact test used $* \mathrm{p}<0.05 * * \mathrm{p}<0.01$ 
Table 2. Results of throat culture and rapid strep test.

\begin{tabular}{|l|l|l|l|}
\hline & $\begin{array}{l}\text { Culture Positive } \\
\text { n (\%) }\end{array}$ & $\begin{array}{l}\text { Culture Negative } \\
\text { n (\%) }\end{array}$ & $\begin{array}{l}\text { Total } \\
\text { n (\%) }\end{array}$ \\
\hline Strep A Positive & $9(7.6 \%)$ & $0(0 \%)$ & $9(7.6 \%)$ \\
\hline Strep A Negative & $3(2.5 \%)$ & $107(89.9 \%)$ & $110(92.4 \%)$ \\
\hline Total & $12(10.1 \%)$ & $107(89.9 \%)$ & $119(100 \%)$ \\
\hline Sensitivity & 75.0 & \\
\hline Specifity & 100 & \\
\hline Positive Predictive Value & 100 & \\
\hline NegativePredictive Value & 97.27 & \\
\hline False Negativity Rate & 2.5 & & \\
\hline False Positivity Rate & 0 &
\end{tabular}


Table 3. Culture and strep test results by McIsaac / modified Centor score.

\begin{tabular}{|l|c|c|c|c|}
\hline McIsaac / Modified Centor & $\begin{array}{c}\text { Culture } \\
\text { Positive }\end{array}$ & $\begin{array}{c}\text { Culture } \\
\text { Negative }\end{array}$ & $\begin{array}{c}\text { Rapid Strep Test } \\
\text { Positive }\end{array}$ & $\begin{array}{c}\text { Rapid Strep Test } \\
\text { Negative }\end{array}$ \\
\hline $\mathbf{2 - 3}$ & $2(2.4 \%)$ & $82(97.6 \%)$ & $1(1.2 \%)$ & $83(98.8 \%)$ \\
\hline $\mathbf{4 - 5}$ & $10(28.6 \%)$ & $25(71.4 \%)$ & $8(22.9 \%)$ & $27(77.1 \%)$ \\
\hline p & \multicolumn{2}{|c|}{$\mathbf{0 . 0 0 1 * *}$} & \multicolumn{2}{|c|}{$\mathbf{0 . 0 0 1 * *}$} \\
\hline
\end{tabular}

Fisher's Exact test $* * \mathrm{p}<0.01$ 
Table 4. Comparison of combined McIsaac / modified Centor score and rapid antigen test with culture positivity.

\begin{tabular}{|c|c|c|c|}
\hline McIsaac / modified Centor score 2-3 & $\begin{array}{l}\text { Culture Positive } \\
\text { n (\%) }\end{array}$ & $\begin{array}{l}\text { Culture Negative } \\
\text { n (\%) }\end{array}$ & $\begin{array}{l}\text { Total } \\
\text { n }(\%)\end{array}$ \\
\hline Strep A Positive & $1(1.2 \%)$ & $0(0 \%)$ & $1(1.2 \%)$ \\
\hline Strep A Negative & $1(1.2 \%)$ & $82(97.6 \%)$ & $83(98.8 \%)$ \\
\hline Total & $2(2.4 \%)$ & $82(97.6 \%)$ & $84(100 \%)$ \\
\hline Sensitivity & \multicolumn{3}{|l|}{50} \\
\hline Specifity & \multicolumn{3}{|l|}{100} \\
\hline McIsaac / modified Centor score 4-5 & $\begin{array}{l}\text { Culture Positive } \\
\text { n (\%) }\end{array}$ & $\begin{array}{l}\text { Culture Negative } \\
\text { n (\%) }\end{array}$ & $\begin{array}{l}\text { Total } \\
\text { n (\%) }\end{array}$ \\
\hline Strep A Positive & $8(22.9 \%)$ & $0(0 \%)$ & $8(22.9 \%)$ \\
\hline Strep A Negative & $2(5.7 \%)$ & $25(71.4 \%)$ & $27(77.1 \%)$ \\
\hline Total & $10(28.6 \%)$ & $25(71.4 \%)$ & $35(100 \%)$ \\
\hline Sensitivity & \multicolumn{3}{|l|}{80} \\
\hline Specifity & \multicolumn{3}{|l|}{100} \\
\hline
\end{tabular}




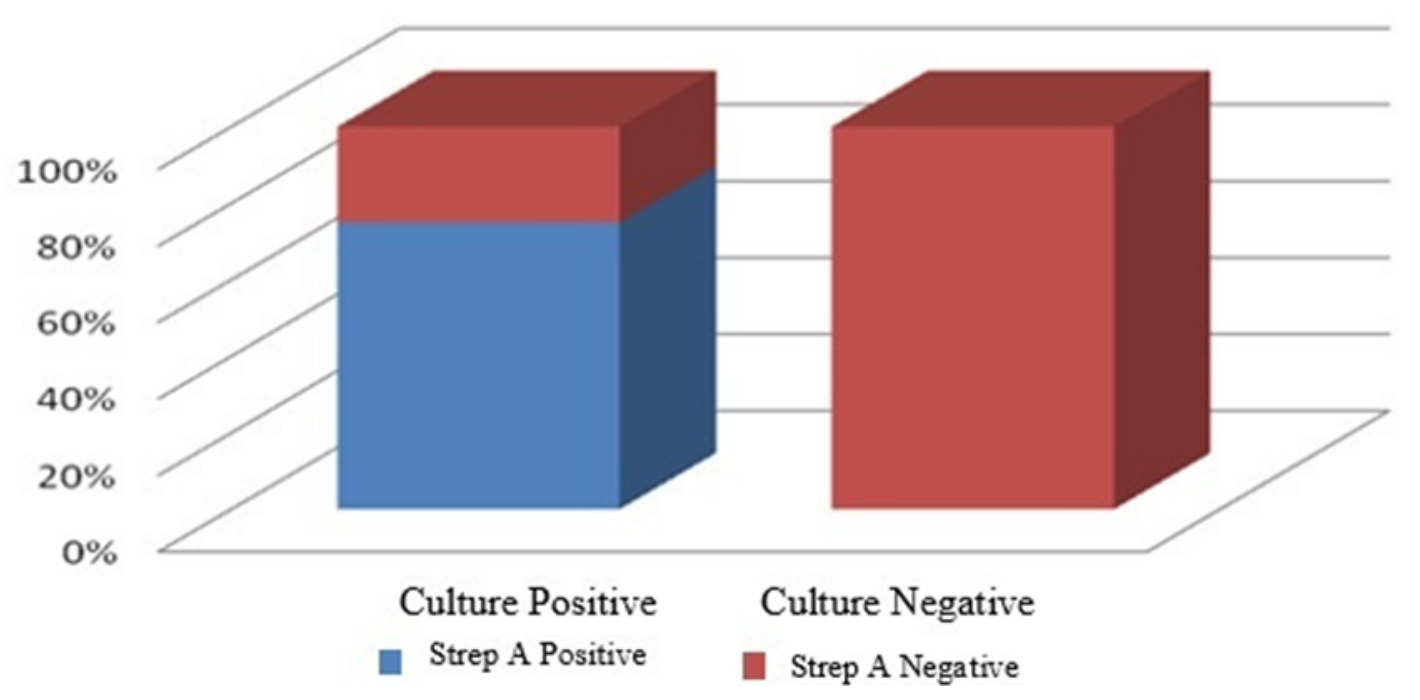

Figure 1. Comparison of Throat Culture and Rapid Strep Test Results. 